\title{
Pemikiran dan Aplikasi Teologi Lingkungan di Pesantren Cicalengka Kabupaten Bandung
}

\author{
Saeful Anwar \\ UIN Sunan Gunung Djati Bandung \\ saefulanawar01@gmail.com \\ Rifki Rosyad \\ UIN Sunan Gunung Djati Bandung \\ rifkirosyad@uinsgd.ac.id
}

\section{Suggested Citation:}

Anwar, Saeful dan Rifki Rosyad (2021). Pemikiran dan Aplikasi Teologi Lingkungan di Pesantren Cicalengka Kabupaten Bandung. Jurnal Iman dan Spiritualitas, Volume 1, Nomor 2: pp 164-175. http://dx.doi.org/10.15575/jis.v1i2.11793

\section{Article's History:}

Received Februari 2021; Revised Februari 2021; Accepted Februari 2021.

2020. journal.uinsgd.ac.id $\odot$. All rights reserved.

\begin{abstract}
Abstrak:
Permasalahan lingkungan ternyata bukan hanya masalah teknis ekologi semata, tetapi juga menyangkut teologi lingkungan, melihat bagaimana relasi antara lingkungan dengan Tuhan melalui pesantren. Tujuan penelitian ini adalah Mengkaji pemahaman teologis, kesadaran dan peran pesantren Al-Faaruuq dan pesantren Bahrul Hidayah terhadap lingkungan. Metode penelitian iani yakni deskriptif-kualitatif untuk mendeskripsikan sejumlah variabel yang berkenaan dengan permasalahan penelitian. Sumber data dalam penelitian ini, yaitu data primer yang bersumber dari informasi yang berasal dari kiai atau ustaz pengasuh pondokdan santri pesantren Al-Faaruuq dan pesantren Bahrul Hidayah. Sedangkan sumber data sekunder yang digunakan dalam penelitian ini bersumber dari dokumen-dokumen berupa (jurnal, riset akademik, artikel, buku dan majalah). Hasil penelitian ini adalah Pertama, pemahaman teologi lingkungan di pesantren al-Faaruuq dan pesantren Bahrul Hidayah Melalui prinsip dasar teologi lingkungan yaitu; 1). Memahami kesatuan Tuhan dan ciptaan-Nya (tauhid) dijadikan pegangan dan pijakan dalam doktrin lingkungan, 2). Melihat tanda-tanda (ayat) Tuhan dimana saja melalui merenungi alam sebagai ciptaan Tuhan, 3). Menjadi penjaga (khalifah) di bumi, dengan cara membentuk karakter santrinya yang mempunyai tanggung jawab sebagai khalifah. 4). Menjaga kepercayaan Tuhan (amanah), merawat lingkungan sebab merupakan amanah dan nanti akan dimintai pertanggungjawaban 5). Berjuang menegakkan keadilan ('adl) membatasi pemanfaatan alam sesuai dengan kebutuhan, 6). Menjalani kehidupan yang seimbang dengan alam (mizan) yaitu melalui harmonisasi relasi manusia-Tuhanalam.
\end{abstract}

\section{Kata Kunci: Teologi; Lingkungan; Pondok Pesantren}

\begin{abstract}
:
Environmental problems are a technical, ecological problem and environmental theology, seeing how the relationship between the environment and God through the pesantren. This study aims to examine the theological understanding, awareness, and role of the Al-Faaruuq and Bahrul Hidayah Islamic boarding schools in the environment. Christian's research method is descriptive-qualitative to describe several variables relating to the research problem. This study's data sources, namely primary data sourced from information derived from kiai or Ustaz caretakers of Al-Faaruuq Islamic boarding school and Islamic boarding school Bahrul Hidayah. Meanwhile, this research's secondary data sources are documents (journals, academic research, articles, books, and magazines). This research aims to understand the environmental theology in Islamic boarding schools alFaaruuq and Islamic boarding school Bahrul Hidayah through the basic principles of ecological theology, namely; 1). Understanding God's unity and His creation (tauhid) is used as guidance and foothold in environmental doctrine, 2). Seeing God's signs (ayat) anywhere through contemplating nature as God's creation, 3). Become a guardian (caliph) on earth by forming the character of his students who are responsible for being caliph. 4). Maintain God's trust (amanah) and care for the environment because it is a mandate and held accountable later 5). Striving to uphold justice ('adl) limiting the use of nature according to needs, 6). Live a life in balance with nature (mizan), namely through harmonizing the human-God-nature relationship.
\end{abstract}




\section{Keywords: Theology; Environment; Islamic Boarding School PENDAHULUAN}

Munculnya wacana teologi lingkungan (ekoteologi) bermula dari artikel Lynn White dalam jurnal Science yang berjudul "The Historical Roots of Our Ecological Crisis (1967)", dalam risetnya tersebut ia menuduh kekristenan Barat serta sains dan teknologi modern sebagai dua sumber masalah krisis lingkungan yang saling terkait satu sama lain. White menuturkan bahwa, maandat Alkitabiah untuk mendominasi alam yang disertai dengan orientasi Kristen yang bersifat antroposentris mengakibatkan munculnya pendekatan ke alam yang bersifat instrumental, bukan yang bersifat menghormati, dan ini kemudian menjadi lahan subur tempat berkembangnya sains dan teknologi yang bersifat destruktif terhadap lingkungan.(Chapman et al., 2008).

Salah satu filsuf Islam yang konsen terhadap isu-isu lingkungan yang dikaitkan dengan konsep teologi (environment philosopher) yaitu Sayyed Hossein Nasr (Islamika, 2016) melalui hasil risetnya yang berjudul "An Introduction to Islamic Cosmological Doctrines (1993)" dan "Religion and the Order of Nature (1996)". Nasr berpandangan bahwa, bumi kita hari ini sedang berdarah-darah oleh luka-luka yang dideritanya akibat ulah manusia yang sudah tidak ramah kepadanya. Pandangan modern dengan ilmu pengetahuannya telah tercerabut dari akar-akar spiritual agama, membuat bumi kiat mengalami krisis dan terus menghampiri titik kebinasaannya. Pada titik inilah, maka peran serta agama untuk menjawab problem lingkungan yang urgen sangat dibutuhkan (Nașr \& Nasr, 1996).

Islam sesungguhnya sudah mempunyai basis teologis yang sangat jelas terkait permasalahan lingkungan. Islam adalah agama yang memandang lingkungan sebagai bagian tak terpisahkan dari keimanan kepada Tuhan. Alam semesta termasuk bumi dan makhluk di dalamnya adalah ciptaan Tuhan (Hidup \& Muhammadiyah, 2011). Oleh karena itu mengenali, memahami dan merawat alam adalah bagian dari iman seseorang kepada Tuhan Yang Menciptakan alam. Dalam rentang sejarah kehidupan manusia telah banyak upaya praktis dalam rangka penyelamatan lingkungan dengan memanfaatkan kemajuan ilmu pengetahuan dan teknologi, namun ternyata belum cukup untuk mengendalikan perusakan lingkungan oleh manusia (Niman, 2019).

Permasalahan lingkungan ternyata bukan hanya masalah teknis ekologi semata, akan tetapi juga menyangkut teologi(Sururi, 2014). Nasr menyarankan bahwa "harus adanya relasi antara nilai-nilai religius agama dan kearifan-kearifan moral yang terjakin. Kemudian Nasr menyebutnya dengan istilah 'ekoteologi', konsep tersebut sangat diperlukan untuk merawat keseimbangan dan keberlanjutan bumi dan alam semesta" (Nașr \& Nasr, 1996). Nasr menantang umat Islam "untuk menyumbangkan pemikirannya dalam masalah lingkungan. Artinya, umat Islam ditantang untuk mendalami rumusan konsep pokok pelestarian alam atas dasar teologi dengan merumuskannya dalam konsep ekologi modern dalam bentuk karya dan kemudian mempraktikkannya sebagai pedoman moral-religius dalam realitas kehidupan sehari-hari"(Nașr \& Nasr, 1996).

Dalam konteks pembahasan ini, "teologi dimaknai sebagai nilai atau ajaran Islam yang berkaitan dengan keberadaan atau keberadaan Tuhan. Oleh karena itu, makna bebas teologi dalam konteks ini adalah cara "menghadirkan" Tuhan dalam setiap aspek kehidupan manusia, termasuk dalam pemanfaatan sumber daya alam dan pengelolaan lingkungan. Sedangkan dalam aspek praktis, teologi dapat diartikan sebagai pedoman normatif bagi manusia untuk berperilaku dan berhubungan dengan alam dan lingkungannya" (Suyatman, 2018).

Kaitannya dengan lingkungan, konsep teologi diturunkan pada wilayah yang bersifat praksis, yaitu dengan melihat bagaimana relasi antara lingkungan dengan Tuhan. Lingkungan bukan sekedar bersifat bio-fisik, namun juga manusia dan makhluk-makhluk lainnya. Upaya penggalian nilai spiritual ekologi lingkungan merupakan pengayaan khazanah ekologi profetik Islam untuk memberikan penawaran dalam konsep ekologi alternatif atau ekologi transformatif (Khitam, 2016). Teologi lingkungan dapat didefinisikan sebagai teologi yang objek kajian materialnya bidang lingkungan, dan perumusannya didasarkan pada nilai-nilai ajaran Islam. Sehingga teologi lingkungan merupakan ilmu yang membahas tentang ajaran dasar Islam mengenai lingkungan (Mujiyono, 2001).

Nilai-nilai teologi Islam dipercaya memiliki daya yang kuat dalam memengaruhi cara pandang (worldview) umat Islam serta mampu menggerakkan perilaku-perilaku manusia dalam menjaga atau merawat lingkungan. Hal tersebut dapat dilihat pada penelitian hasil Ali Murtadho dan Mahzumi maka dapat dinyatakan bahwa "dalam konteks beragama, kepedulian terhadap lingkungan amat bergantung pada aktor yang menggerakkan yang berkaitan dengan aspek ajaran agama mengenai lingkungan. Dalam bahasa Abdullah bahwa persoalan lingkungan harus disajikan dan dieksplorasi oleh para tokoh penggeraknya dengan menggunakan bahasa serta idiom-idiom sederhana tentang ekologis".(Abdullah \& Mubarak, 2010). Peran serta ulama menjadi sangat sentral sebagai pelopor dan penggerak di kalangan umat Islam dan diharapkan mampu merubah kesadaran masyarakat.dalam penelitiannya yang "menemukan tipologi baru dalam gerakan sosial mengusung isu lingkungan beridentitas agama dari kalangan muda NU, di mana para aktornya adalah para santri progresif menggunakan pola segitiga jejaring silaturahmi dalam gerakan sosial. Tipologi baru ini dekat dengan tipologi gerakan lingkungan yang dibuat Manuel Castells". Hal serupa juga dapat dilihat dalam penelitian Fikri Mahzumi, yang menyatakan "bahwa untuk membangun kesadaran dan aksi ekologis, maka Islam dan tradisi bisa saling mengisi, sehingga terwujud citra sebenarnya dari manusia sebagai khalifah Allah fi al-ard (utusan Allah di bumi)" (Murtadho, 2019).

Salah satu institusi keagamaan yang dituntut berperan dalam penanggulangan masalah lingkungan di dalam Islam yaitu pesantren. Sebab pesantren sebagai institusi pendidikan Islam harus memainkan peran yang penting dalam pembangunan masyarakat, seperti meningkatkan keimanan, meningkatkan ketakwaan, membimbing akhlak dan serta turut mencerdaskan 
kehidupan bangsa melalui pendidikan informal. Pesantren juga memberikan suatu respon terhadap krisis lingkungan yaitu hadirnya buku Fiqih Lingkungan ( Fiqh al-Bi'ah ) pada tahun 2004 yang digagas oleh para Ulama dari Nahdlatul Ulama. Hasil dari rembugan para ulama dalam pertemuan tersebut merekomendasikan (Muhammad et al., 2006).

Menurut data Kementerian Agama tahun 2020, di Jawa Barat tercatat memiliki pesantren sebanyak 8.343 dengan satuan pendidikan sebanyak 5.465 dan penyelenggara satuan pendidikan sebanyak 2.878 . sedangkan jumlah santrinya sebanyak 455.715dengan rincian santri yang mukim sebanyak 148.987 sedangkan santri yang tidak mukim sebanyak 306.728 (Kemenag, 2020). menurut Mangunjaya, "jika ditinjau dari segi lokasinya 78\% pesantren terdapat di daerah pedesaan. Hal tersebut menjadi indikasi bahwa pesantren mungkin dapat berpotensi sebagai lokomotif bagi penularan kesadaran pada konservasi, pembangunan lingkungan dan mempengaruhi komunitasnya" (Mangunjaya, 2014).

Sedangkan jumlah pesantren di Kabupaten Bandung menurut data Kementerian Agama tahun 2020, tercatat memiliki pesantren sebanyak 127 dengan tipe pesantren satuan pendidikan sebanyak 45 dan penyelenggara satuan pendidikan sebanyak 82 pesantren. Sedangkan total santrinya sebanyak 14.022 dengan rincian santri yang mukim sebanyak 8.955 sedangkan santri yang tidak mukim sebanyak 5.067 santri (Kemenag, 2020). Sesungguhnya data pesantren yang ada di Kabupaten Bandung masih banyak yang tidak tercatat dikarenakan corak pesantrennya salafiah dan tidak mempunyai akte Yayasan, sebagaimana yang di kemukakan oleh Abdul Aziz, yang mengatakan bahwa di FPP (Forum Pondok Pesantren) Kabupaten Bandung yang terdaftar baru 400 an pondok pesantren padahal pondok pesantren yang ada itu lebih dari 1000 an. Dari jumlah 400 an itu 60\% nya pesantren salafiah (tradisional) sedangkan sisanya pesantren khalafiyah (modern). (Wawancara dengan Ustad Aziz, Pengurus Pesantren Al-Faruq, Cicalengka, 18 Desember 2020).

Dofier mengklasifikasikan pesantren menjadi dua varian yang didasarkan pada kajiannya pada keterbukaan (inklusivitas) pesantren pada perubahan sosial, yakni "salafi dan khalafi. Pesantren Salafiah adalah pesantren yang memelihara pengajian kitab-kitab klasik Islam (turats) sebagai inti pendidikan dan pengajaran di pesantrennya. Sistem kelas (madrasah) diterapkan untuk memfasilitasi sistem sorogan (pengajian) yang digunakan di lembaga pengajian Islam lama, tanpa mengajarkan pengetahuan umum, sedangkan pesantren khalafiah yaitu pesantren yang telah menggunakan sistem klasik (madrasah) dan terintegrasi dengan pendidikan formal. (sekolah umum)" (Dhofier, 1982).

Corak pesantren di Cicalengka yaitu bercorak salafiah dan khalafiah dengan berbagai variannya masing-masing. Dalam sejarah perkembangan pesantren di Cicalengka, tercatat bahwa pesantren tertua di Cicalengka adalah pesantren pesantren Pamoyanan (sekarang pesantren Husainiyah) yang didirikan tahun 1873 yang dirintis oleh Mama KH. Husain oleh sebab itu kemudian dinamakan Husainiyah, beliau mempunyai mantu yang bernama Mama KH. Abas Toha yang meneruskan pesantren setelah Mama KH. Husain meninggal. Pendiri pesantren al-Hidayah (Santiong) yaitu Mama KH. Muhammad Sukhrowardi merupakan murid dari Mama KH. Husain dan Mama KH. Abas Toha dan pernah menikah dengan putra Mama KH. Husain. Pesantren Al-Falah yang berdiri pada tahun 1970 juga masih berkaitan secara nasab, namun pesantren Al-Faaruuq masih lebih dahulu berdiri ketimbang al-Falah yaitu tahun 1974 yang didirikan oleh KH. Ucid Sanusi sedangkan majelis taklimnya sudah berdiri sejak 1923. Setelah Pesantren Pamoyanan berdirilah pesantren Cikalama (parakan muncang sumedang) terus berdirilah pesantren Sukahurip Cikancung, terus berdiri juga At-Tuba Cikancung, baru setelah itu berdiri Al-Faaruuq kemudian berdirilah alfalah. Masjid Jami Al-Faaruuq dibangun setelah masjid Jami Pamoyanan. (Wawancara dengan Ustad Abdul Azis, Pengurus pesantren al-Faaruuq, Cicalengka 18 Desember 2020).

Dikarenakan banyaknya jumlah pesantren yang ada di Cicalengka dengan beragam corak atau warna pesantren, dalam penelitian ini penulis memilih 2 objek penelitian yaitu pesantren al-Faaruqq, dan pesantren Bahrul Hidayah yang keduanya mempunyai corak salafi dengan pembedaannya terletak pada wilayah domisilinya kalau pesantren al-Faaruqq terletak di kota kecamatan sedangkan pesantren Bahrul Hidayah terletak dipedesaan (pegunungan).

Objek penelitian yang pertama adalah pesantren Al-Faaruuq yang beralamat di Desa Tenjolaya Kecamatan Cicalengka merupakan pesantren yang bercorak salafiah (tradisional). Ulama yang mendirikan pesantren Al-Faaruuq adalah KH. Ucid Sanusi pada tahun 1974, namun masjid Jaminya sudah berdiri sejak tahun 1923. Akses ke pesantren dari pusat kota kecamatan bisa ditempuh 5 menit menggunakan kendaraan bermotor. Pesantren al-Faaruq berada di tengah-tengah pemukiman masyarakat perkotaan, dekat dengan jalan raya Bandung-Garut dan berada di pinggir sungai Citarik, sehingga peneliti tertarik untuk meneliti pesantren tersebut yang kaitannya antara pesantren dengan teologi lingkungan untuk melihat bagaimana pemahaman, kesadaran serta peran pesantren dalam merawat dan menjaga lingkungan sekitar dan bentuk aksinya.

Objek penelitian yang kedua adalah pesantren Bahrul Hidayah yang didirikan pada tahun 2007, berlokasi di kampung Leuwiliang Desa Tanjungwangi Cicalengka merupakan pesantren yang bercorak salafiah. Secara demografi lokasi pesantren tersebut berada di daerah pegunungan yang berdekatan dengan Taman Konservasi Taman Buru Gn. Masigit-Kareumbi. Untuk mencapai lokasi pesantren dibutuhkan waktu 30 menit dengan menggunakan kendaraan bermotor. Beberapa tahun terakhir di daerah sekitar pesantren Bahrul Hidayah sering terjadi banjir bandang kiriman dari kawasan hutan konservasi. Berdasarkan fakta tersebut, peneliti tertarik mengeksplorasi lebih jauh bagaimana teologi lingkungan yang diajarkan pesantren kepada para santrinya dan bagaimana aksi yang dilakukannya kepada masyarakat sekitar.

Kecamatan Cicalengka dipilih sebagai lokasi penelitian, dikarenakan lokasi tersebut mempunyai sejarah dan pengaruh besar dalam penyebaran agama Islam serta produktivitas santri atau kuantitas pesantren yang ada di Kabupaten Bandung. Kecamatan Cicalengka yang terletak di sebelah Timur Bandung, merupakan daerah yang bersejarah, sebab di sana terdapat kerajaan Kendan (Histori.id, 2020) yang berdiri 612 masehi merupakan leluhur kerajaan di tatar Pasundan yakni kerajaan 
Galuh dan Pakuan Pajajaran. Kendan merupakan sebuah kerajaan kecil yang bercorak keagamaan (karesian) yang di pimpin oleh Resiguru Manikmaya (536-568 M) berdirinya kerajaan Kendan bertujuan untuk menyebarkan agama Hindu di tanah Jawa. Berdasarkan jejak sejarah, maka tak heran bahwa Cicalengka merupakan pusat dari penyebaran agama.

Di wilayah Cicalengka perubahan masyarakat yang sangat signifikan dari masyarakat yang bersifat agraris beralih kepada masyarakat industri hal tersebut ditandai dengan berdirinya pabrik-pabrik tekstil. Secara konsekuensi akan mengubah perspektif masyarakat pada kehidupan keseharian dan berdampak pada lingkungannya. Dengan dibangunnya pabrik-pabrik tekstil di sepanjang jalan raya Bandung-Garut maka mengakibatkan meledaknya demografi penduduk. Oleh sebab itu banyak lahan produktif dijadikan sebagai kompleks pemukiman, juga sudah merembet ke area RTH (ruang terbuka hijau) yang diperuntukkan untuk area resapan air. Diperparah lagi dengan dibangunnya wahana wisata Dream Land dengan luas area 47 hektar yang tentunya berefek negatif pada lingkungan, sebagaimana yang dipaparkan oleh pihak Basarnas, bahwa kesadaran masyarakat disini saya lihat masih rendah. Harus ada perjuangan dari pemerintah daerah setempat baik dari desa, kecamatan, maupun kabupaten harus selalu membimbing masyarakat bagaimana membuang sampah, bagaimana reboisasi di tempat yang seharusnya banyak pohon, tidak membangun di area zona hijau. Jika membangun di daerah resapan air di daerah atas dengan tembok/beton yang konsekuensinya akan menggerus air yang turun ke bawah tanpa ada penyangga atau peresapan (Wawancara dengan Iwan Ramdani, Staf SDM Kansar Bandung, Cicalengka 18 Desember 2020).

Perubahan pada masyarakat tak bisa diejawantahkan, sebab manusia adalah makhluk berbudaya. Perubahan yang terjadi bisa bersifat lambat atau cepat tergantung kontak sosial masyarakat tersebut. Sebelum dibangunnya pabrik industri mata pencaharian penduduk Cicalengka mayoritas petani. Dampak dari pergeseran paradigma masyarakat tersebut akan berakibat pada hilangnya hubungan antara manusia dengan lingkungan, raibnya relasi antar manusia, dan terasingnya rebungan dengan masyarakat. Budaya konsumsi yang merajalela yang condong individualistis yang kemudian tumbuh dalam diri seseorang yang pada akhirnya akan membuat manusia tercerabut dari relasinya dengan alam. Albert Einstein berkata bahwa upaya pelumpuhan individu ini kuanggap sebagai kejahatan terburuk kapitalisme. Keseluruhan sistem pendidikan kita menderita akibat dari kejahatan ini. Sikap kompetitif berlebihan ditanamkan kepada pelajar, yang dilatih untuk memuja keberhasilan memiliki sebagai persiapan bagi karier-kariernya di masa depan (Magdoff \& Foster, 2018).

Penelitian ini menjadi sangat penting untuk dikaji dalam analisis teori fakta sosial dan solidaritas sosial Emile Durkheim. Teori tersebut hendak melihat kecenderungan pesantren apakah mentalitasnya didasarkan pada solidaritas organik atau mekanik, yaitu aktivitas pesantren itu bukan berdasarkan inisiatif individu tapi inisiatif kesadaran kelompok atau kolektif. Lebih jauh lagi, diharapkan penelitian ini dapat melihat apakah pesantren melakukan aktivitas lingkungan di dasarkan atas doktrin teologis atau berdasarkan kesepakatan kolektif semata. Jika menggunakan Durkheim apakah ada perilaku kolektif. Perilaku kolektif yang memunculkan kesadaran doktrin bukan pengetahuan doktrin.

\section{METODE}

Metode penelitian iani yakni deskriptif-kualitatif. "Penelitian kualitatif (qualitative research) dipandang sebagai prosedur penelitian yang dapat menghasilkan data deskriptif berupa kata-kata tertulis atau lisan dari orang atau perilaku yang dapat diamati" (Moleong, 2007). Sedangkan "penelitian deskriptif, dimaksudkan untuk eksplorasi dan klarifikasi mengenai sesuatu fenomena atau kenyataan sosial, dengan jalan mendeskripsikan sejumlah variabel yang berkenaan dengan masalah dan unit yang diteliti (Sanapiah, 1995)." Metode kualitatif-deskriptif ditujukan untuk menganalisis fenomena permasalahan lingkungan di pesantren Al-Faaruuq dan pesantren Bahrul Hidayah, untuk melihat bagaimana kesadaran masyarakat pesantren dalam mengatasi permasalahan lingkungan seperti banjir, longsor dan permasalahan sampah. Juga memahami bagaimana konsep atau gagasan teologi lingkungan yang dipahami pesantren Al-Faaruuq dan pesantren Bahrul Hidayah serta bagaimana dalam tataran aksinya.

Sumber data dalam penelitian ini dibagi menjadi dua, yaitu data primer dan data sekunder. Sumber data utama (sumber primer) yang digunakan dalam penelitian ini bersumber dari informasi lapangan yang berasal dari sejumlah kiai atau ustaz pengasuh pondok pesantren Al-Faaruuq dan pesantren Bahrul Hidayah, santri yang belajar di beberapa pondok pesantren AlFaaruuq dan pesantren Bahrul Hidayah. Sumber data sekunder yang digunakan dalam penelitian ini bersumber dari informasi lapangan yang berasal dari masyarakat sekitar pesantren Al-Faaruuq dan pesantren Bahrul Hidayah, para aktivis lingkungan, juga instansi Basarnas. Sedangkan literatur yang menjadi sumber data sekunder meliputi dokumen-dokumen yang merupakan hasil laporan penelitian (jurnal, riset akademik, artikel, majalah) yang berkaitan dengan masalah teologi lingkungan serta bukubuku yang ditulis yang dipandang relevan dengan masalah yang sedang diteliti.

Dalam hal pengumpulan data, Peneliti sendiri secara langsung mengumpulkan data di lapangan dalam situasi nyata. Teknik pengumpulan data dalam penelitian ini menggunakan observasi dan wawancara mendalam. Analisis Data dalam penelitian mnggunkan proses-proses analisis kualitatif menurut Miles \& Huberman dapat dijelaskan dalam tiga langkah yakni: Reduksi Data (data reduction), Penyajian data (data display), Kesimpulan (conclusion and drawing).

\section{HASIL DAN PEMBAHASAN}

\section{Pemahaman Teologi Lingkungan di Pesantren}

\section{a. Memahami Kesatuan Tuhan dan Ciptaan-Nya (Tauhid)}


Allah merupakan pencipta langit dan bumi dan segala isinya, yang merupakan satu-satunya Tuhan yang menciptakan alam yang sangat mengagumkan ini. Selayaknya manusia harus mampu merawat semua ciptaan Allah. Memahami lingkungan harus berdasarkan pada tauhid seperti pendapat ustaz Apip yang mengungkapkan bahwa, Dalam konteks masalah lingkungan, nilai tauhid harus dijadikan sebagai dasar pegangan atau tindakan santri dan masyarakat dalam memahami alam ini. Alam harus dilihat sebagai ayat atau simbol yang sehingga mampu mengantarkan manusia untuk sampai pada realitas sejati. Alam memang diciptakan untuk manusia, namun berbagai hak yang dimiliki manusia hanya berupa hak pemanfaatan yang nantinya akan diminta pertanggungjawaban (Wawancara dengan Apipudin, Pengasuh pesantren Bahrul Hidayah, Cicalengka 20 Desember 2020).

Semua tindakan manusia bukan hanya saja hubungan manusia dengan Tuhan, hubungan manusia dengan manusia, atau hubungan manusia dengan alam harus disandarkan pada akidah atau tauhid. Pesantren Bahrul Hidayah merupakan tempat dalam belajar bagi santri dan menyebarkan ajaran Islam kepada masyarakat khusnya kampung Leuwiliang Cicalengka. Memberikan cara pandang lingkungan yang berbasis pada tauhid dalam melihat segala sesuatu yang ada di alam ini yang semuanya bersumber dari Allah dan akan kembali kepada Allah, bahkan semuanya mengelilingi Allah. Ustaz Apip memahami bahwa alam ini beserta isinya diciptakan (creation) dan didesain oleh Allah dengan tujuan dan keberlangsungan atau pemeliharaannya (maintenance) pun di jaga Allah. Manusia memiliki hak dan kewajiban dalam mengelola lingkungan.

Tauhid harus dijadikan sebagai pegangan dalam doktrin lingkungan juga ditegaskan oleh ustaz Aziz melalui pendapatnya yang mengatakan bahwa, , konsep tauhid dapat dijadikan sebagai sumber doktrin teologi lingkungan. Sebab semua penampakan alam semesta merupakan tanda-tanda (ayat) eksistensi Allah. Dan segala sesuatu merupakan manifestasi Allah, dan semuasnya berasal dari-Nya. Oleh sebab itu prinsip dasar dalam seluruh ajaran Islam harus bersandarkan pada tauhid. Dalam merenungkan prinsip teologi lingkungan dan mempraktikkannya dalam syariat Islam seraya mengaitkan antara iman dengan lingkungan dapat di mulai melalui praktik salat. Melalui salat, kita bisa merenungkan hubungan manusia dengan Tuhan dan dengan planet ini serta bagaimana kita hidup di dalamnya (Wawancara dengan Abdul Aziz, Pengasuh pesantren AlFaaruuq, Cicalengka 20 Desember 2020).

Aspek penting dalam tauhid bukan hanya penegasan Keesaan Allah semata, namun menyangkut dengan segala ciptaanNya. Mengetahui bahwa Allah adalah pencipta semesta alam dan satu-satunya penguasa segenap makhluk. Oleh karena itu setiap makhluk harus diperlakukan dengan berprinsip pada tauhid, atau merujuk pada penciptanya. Sesungguhnya Allah tidak menciptakan makhluknya dengan sia-sia, faktanya bahwa setiap makhluk yang Dia ciptakan seluruhnya mempunyai nilai dan makna. Selain itu, Allah menciptakan segala sesuatu bilhaqq, dalam kebenaran dan untuk kebenaran. Sebagaimana dalam firman Allah dalam Al-Qur'an Surat Ad-Dhukan ayat 38-39 yang artinya: "Dan tidaklah Kami bermain-main menciptakan langit dan bumi dan apa yang ada di antara keduanya. Tidaklah Kami ciptakan keduanya melainkan dengan haqq (benar), tetapi kebanyakan mereka tidak mengetahui". Sesungguhnya Allah menciptakan alam raya demi kemaslahatan umat manusia, namun kebanyakan orang mengingkarinya. Bagaimana cara hidup dalam bingkai teologi lingkungan, maka prinsip dasarnya harus mengerti bahwa segala sesuatu yang ada di alam semesta atau segala sesuatu yang ada, semuanya berasal dari Allah.

\section{b. Melihat Tanda-tanda Kebesaran Tuhan (Ayat)}

Manusia dalam memanfaatkan alam tidak diperkenankan untuk mengganggu, merusak yang berakibat pada hilangnya keseimbangan ekologinya yang memang sudah ditetapkan dengan hukum Tuhan dalam pola yang sedemikian indah dan harmonis. Hendaknya manusia melihat kebesaran Tuhan melalui tanda-tandanya (ayat) yang tampak di seluruh semesta, bukan malah acuh tak acuh, hal tersebut di kemukakan oleh ustaz Apip, yang mengemukakan bahwa, penebangan pohonpohon di hutan secara liar dan tidak bertanggung jawab, membuang sampah ke sungai, perilaku seperti itu akan menimbulkan bahaya besar bagi masyarakat yang bisa menimbulkan bencana. Seperti lima tahun terakhir di sini sering terjadi banjir bandang dari kawasan Kareumbi. Sesungguhnya Islam sudah mengajarkan pada kita untuk merawatnya, sebab lingkungan merupakan ciptaan Allah maka tugas manusia adalah merawatnya (Wawancara dengan Apipudin, Pengasuh pesantren Bahrul Hidayah, Cicalengka12 Januari 2021).

Hal tersebut juga kemudian di kemukakan oleh ustaz Aziz yang mengatakan bahwa, Semua tanda-tanda yang ada di alam semesta merupakan bukti kekuasaan Allah. Kita harus memperluas sudut pandang agar mampu melihat dan memahami bukti-bukti yang nyata dan tak terbantahkan. Apa yang kita lihat melalui mata, apa yang kita rasakan melalui nafas dan detak jantung, apa yang kita ucapkan semuanya mencerminkan kekuasaan Allah. Dengan merenungkan tanda-tanda kebesaran Allah yang terhampar di sekeliling kita, berarti kita tengah merenungkan hakikat diri sejati kita (Wawancara dengan Abdul Aziz, Pengasuh pesantren Al-Faaruuq, Cicalengka 20 Desember 2020).

Sebagaimana yang dikemukakan oleh ustaz Apip bahwa, lingkungan harus dicintai, dijaga, dasarnya kebersihan sebagian dari iman, lalu aturan di setiap lembaga mempunyai aturannya masing-masing, kalau saya suka mencontohkannya melalui tindakan. Contohnya sebelum menyuruh santri membersihkan lingkungan, kita harus memberikan contoh terlebih dahulu dan ikut bersama santri dalam membersihkannya, dan santri juga diberikan pelajaran bagaimana mengelola sampah seraya mengajak santri untuk merenungkan bahwa alam semesta merupakan titipan Allah, oleh sebab itu harus dijaga dan dirawat (Wawancara dengan Apipudin Pengasuh pesantren Bahrul Hidayah, Cicalengka 20 Desember 2020).

Dasar pertama yang harus diterapkan kepada santri pesantren Bahrul Hidayah yaitu kebersihan lingkungan baik itu asrama (kobong), masjid, madrasah harus selalu bersih. Dalam mengelola sampah, santri dibiasakan memilah antara sampah organik dan sampah sampah nonorganik. Untuk sampah yang organik dijadikan pupuk sedangkan sampah anorganik dibakar 
di belakang pesantren, dan sisa hasil pembakarannya di kubur dalam tanah. Dalam pelaksanaannya ada jadwal piket santri. Khusus hari Jumat seluruh santri ikut terlibat dalam aktivitas kebersihan lingkungan pesantren termasuk para pengasuhnya. Menurut Ustaz Apip, "kebersihan lingkungan merupakan tanggung jawab bersama"(Wawancara dengan Apipudin Pengasuh pesantren Bahrul Hidayah, Cicalengka12 Januari 2021).

Dipesantren Al-Faaruuq pun sama dengan pesantren Bahrul Hidayah dalam mengelola kebersihan pesantren dilakukan oleh santri melalui piket harian. Namun yang membedakan yaitu melibatkan orang yang tidak mampu bersama santri dalam ikut merawat kebersihan pesantren. Seperti ungkapan ustaz aziz bahwa, di pesantren Al-Faaruuq alhamdulillah hampir dua tahun kebersihan khusus di lingkungan pesantren kita paksa untuk selalu bersih dengan pola memberdayakan orang yang kurang mampu. Seperti Ato mempunyai jadwal seminggu sekali kesini dan dibantu oleh santri untuk bersih-bersih. Siapa yang kerasan tinggal di lingkungan kotor. Sebetulnya dari konsep teologi Islam, sudah sempurna dalam Al-Qur'an disebutkan innalloha yuhibbuttawabina wa yuhibbul mutathohhirin sesungguhnya Allah menyukai orang yang bertaubat dan menyukai orang yang bersih. Dalam mengaji, saya selalu mengajak santri untuk merenungkan tanda kebesaran Allah melalui lingkungan (Wawancara dengan Abdul Aziz, Pengasuh pesantren Al-Faaruuq, Cicalengka 20 Desember 2020).

Salah satu cara untuk memahami ayat-ayat Tuhan di bumi adalah dengan merenungkannya. Seperti yang diterapkan di Pondok Pesantren Al-Faaruuq dan pesantren Bahrul Hidayah, yaitu ketika santri membaca ayat-ayat Alquran dapat dimaknai sebagai memahami ayat-ayat Tuhan, yaitu ketika membaca sekaligus kita harus merenungkan maknanya di dalamnya. ayatayat. Al-Qur'an, ini bisa dianggap sebagai seseorang yang berjalan di alam semesta.

Maka untuk memahami tanda-tanda kebesaran Allah harus dimulai dari aktivitas lingkungan di pesantren, nanti juga akan memperluas pada wilayah yang lainnya. Sesungguhnya di dalam teks Al-Qur'an terdapat ayat-ayat membahas struktur eksistensi kehidupan di alam semesta. Oleh sebab itu, melatih akal untuk senantiasa berpikir merupakan suatu upaya untuk dapat memahami semua fenomena alam yang ada di sekeliling manusia, merupakan bentuk dari pesan dan tanda dari Ketuhanan.

\section{c. Menjadi Penjaga Bumi (Khalifah)}

Menjaga bumi ini berarti menjaga kelestarian fungsi bumi sebagai tempat tinggal makhluk Tuhan, termasuk manusia, serta menjaga keberlangsungan hidup mereka. Islam memandang manusia sebagai khalifah Tuhan di bumi dan sebagai proyeksi dimensi vertikal ke dalam bidang horizontal. Ajaran dasar Islam tidak dikotomi antara wilayah eksoterik (kehidupan dunia) dan wilayah esoterik (akhirat). Melalui instrumen akal manusia mampu mengetahui realitas yang ia sendiri menjadi salah satu perwujudannya. Sebagaimana penuturan Ustaz Aziz bahwa, manusia dalam pandangan Islam, merupakan ciptaan Allah yang paling sempurna dibandingkan makhluk ciptaan Allah yang lainnya. Manusia dikaruniai akal, pikiran dan intuisi. Oleh sebab itu manusia memikul peran sebagai wakil Allah di muka bumi (khalifah). Kita semua adalah para pelindung bumi. Kita diciptakan oleh Allah dalam kesempurnaan. Oleh sebab itu, manusia mempunyai kewajiban dalam mengelola lingkungan dengan baik. Pesantren merupakan lembaga pendidikan dalam mencetak manusia-manusia unggul yang berkarakter (Wawancara dengan Abdul Aziz, Pengasuh pesantren Al-Faaruuq, Cicalengka 20 Desember 2020).

Dalam prinsip teologi lingkungan berarti memahami bahwa Tuhan menciptakan manusia dari tanah, kemudian manusia harus bertindak dalam menjaga kelestarian alam, melindunginya, dan mengelolanya sebagai karunia yang terkandung di dalamnya melalui cara menjaga keseimbangannya dan tidak merusaknya. Pesantren adalah lembaga pendidikan yang membentuk karakteristik muslim yang taat dan mempunyai akhlak yang baik sebagaimana di contohkan oleh Rasulullah. Sebab manusialah yang harus mempunyai tanggung jawab dalam mengelola lingkungannya, jika bukan manusia siapa lagi yang akan mengelolanya karena manusia yang di bekali akal dan pikiran. Apa yang dikemukakan ustaz aziz di atas dijadikan pijakan bahwa Islam mempunyai tanggung jawab dalam mengelola lingkungan.

Untuk menjalankan misi khilafah ini manusia telah dianugerahi oleh Tuhan kelebihan dibandingkan dengan makhluk lain, yakni kesempurnaan ciptaan dan akal budi yang tidak diberikan oleh Tuhan kepada makhluk lainnya. Dengan berbekal akal budi (akal dan hati nurani) ini manusia mestinya mampu mengemban amanat untuk menjadi pemimpin sekaligus wakil Tuhan di muka bumi. Sebagai pemimpin semua makhluk, manusia harus bisa menegakkan amanah dan keadilan ditengah-tengah lingkungan alamnya di muka bumi ini, termasuk dalam lingkungan sosial. Oleh sebab itu, saya selalu menekankan kepada para santri Bahrul Hidayah bahwa keberlangsungan alam ditentukan oleh tindakan manusia (Wawancara dengan Apipudin, Pengasuh pesantren Bahrul Hidayah, Cicalengka 20 Desember 2020).

Manusia yang diwakili oleh "Nabi Muhammad SAW dan para pengikutnya memiliki kewajiban yang sangat besar yaitu kewajiban menjaga alam karena posisinya yang merupakan berkah bagi semua makhluk. Kewajiban ini ada relevansinya dengan kedudukan manusia sebagai khalifah atau sebagai pemimpin di muka bumi yang dalam kondisi tertentu sering disalahartikan sebagai penguasa bumi atau bahkan pemiliknya. Padahal, meskipun manusia memiliki kewenangan untuk mengeksploitasi sumber daya, di sisi lain terdapat kewajiban untuk melindunginya. Secara umum berbagai permasalahan lingkungan yang muncul harus dilihat dan dikaji pada akar permasalahannya".

Tentunya pesantren merupakan tempat yang tepat dalam mengatasi persoalan lingkungan, sebab pesantren memiliki peran yang signifikan dalam membentuk karakter santri yang berakhlakul karimah dan mempunyai kesadaran sosial yang tinggi sebagaimana yang di contohkan oleh Nabi Muhammad. Pesantren Al-Faaruuq dan pesantren Bahrul Hidayah bertujuan untuk membentuk karakter santrinya yang mempunyai tanggung jawab sebagai khalifah. Dalam mendidik santrinya kedua pesantren tersebut bukan hanya memberikan pendidikan pengetahuan Islam dalam bentuk teori tapi juga dalam 
pengaplikasiannya di dalam kehidupan keseharian. Pesantren tentunya mewadahi kedua bentuk tersebut baik secara teori maupun aksinya. Santri dibekali pengetahuan tentang lingkungan yang bersumber dari ilmu-ilmu keislaman maupun ilmu-ilmu sosial, tapi juga harus mampu diaplikasikan di lingkungan pesantren secara khusus dan di lingkungan masyarakat secara luas.

\section{d. Menjaga Amanat Tuhan (Amanah)}

Sebagai dalam menjalankan amanah Tuhan, manusia hendaknya "tidak bertindak eksploitatif dan merusak alam yang akan menyebabkan manusia menerima murka Tuhan dan digolongkan sebagai pelaku kesalahan". Untuk menjaga keberlanjutan dan memenuhi mata pencahariannya, manusia berhak memanfaatkan apapun yang ada di bumi (sumber daya alam) di bumi. Namun, baik individu maupun kelompok tidak memiliki hak mutlak untuk menguasai sumber daya alam yang bersangkutan. Hak untuk mengontrol tetap pada Tuhan Pencipta. Manusia wajib menjaga amanah atau amanah yang telah diberikan oleh Allah SWT.

Pada dasranya manusia diciptakan oleh Allah dan hidup di dalam dunia ini dengan membawa kepercayaan Allah, oleh sebab itu kita harus bisa mempertanggungjawabkan amanah tersebut. Kita sudah diberikan oleh Allah kemampuan berpikir, kemampuan berpengetahuan dan kemampuan untuk membuat pilihan dan keputusan atas lingkungan yang kita diami, oleh sebab itu jangan sekali-kali kita melalaikan tugas kita sebagai khalifah (Wawancara dengan Abdul Aziz, Pengasuh pesantren Al-Faaruuq, Cicalengka 11 Januari 2021).

Karena manusia diciptakan oleh Tuhan dengan beriman, oleh karena itu hubungan antara manusia dengan lingkungannya merupakan bagian dari eksistensi sosial yang merupakan wujud eksistensi bahwa apapun yang ada di muka bumi ini mempunyai kewajiban untuk menyembah Tuhan. Ibadah ini bukan sekedar ritual simbolik, melainkan manifestasi manusia dalam penyerahan diri kepada Sang Pencipta. Dalam konteks ini, alam, khususnya bumi tempat tinggal manusia, merupakan arena atau ajang uji coba bagi manusia. Agar manusia berhasil dalam ujiannya, ia harus mampu membaca "tanda" atau "ayat" alam yang ditunjukkan oleh Pengendali Tertinggi Alam. Salah satu syarat agar manusia bisa membaca ayat-ayat Tuhan, manusia harus memiliki ilmu dan ilmu.

Sesungguhnya apa yang dilakukan oleh seseorang dalam kaitannya dengan lingkungan apakah bertindak merusak, atau memanfaatkan alam secara berlebihan sehingga bertindak semena-mena, hal ini menunjukkan bahwa dalam konteks keimanan orang tersebut menjadi sangat rapuh karena bersikap tidak amanah. Dikarenakan tindakannya dapat merugikan orang banyak (Wawancara dengan Abdul Aziz, Pengasuh pesantren Al-Faaruuq, Cicalengka 11 Januari 2021).

Menurut pendapat Ustaz Aziz bahwa manusia hanya dititipi saja oleh Tuhan dalam mengelola alam, sebagaimana yang diungkapkannya, bahwa, alam semesta beserta segala isinya merupakan milik Allah. Status manusia hanya sekedar pengelola dan pemelihara alam dalam kerangka pemenuhan kehidupan yang sewajarnya. Namun karena ketamakan manusia, sehingga manusia di sana-sini mengeruk alam tanpa merasa puas. Seperti mendirikan bangunan di lahan resapan air, yang pada akhirnya menimbulkan bencana bagi dirinya atau orang lain (Wawancara dengan Abdul Aziz, Pengasuh pesantren Al-Faaruuq, Cicalengka 11 Januari 2021).

Sesungguhnya kepemilikan manusia tersebut hanyalah bersifat amanah, (titipan atau pinjaman) yang kelak harus dikembalikan kepada yang punyanya dengan mempertanggung jawabkan kepada pemilik-Nya. Dalam kaitannya dengan konsep amanah, Matin membagi dua karakter orang dalam memandangnya, "pertama, sebagian orang mempercayai bahwa perjanjian kita dengan Allah (amanah) mengandung arti bahwa kita adalah makhluk bumi yang paling unggul sehingga kita mempunyai hak untuk melakukan apa pun yang kita inginkan di atas bumi-mengambil apa pun yang kita inginkan serta menggunakannya sekehendak hati tanpa mempertimbangkan dampak konsumsi. Kedua, sebagian orang bertanggungjawab untuk merawat planet ini, menjaganya dan memandangnya sebagai 'pinjaman' dari sang pencipta" (Abdul-Matin, 2010).

\section{e. Memperjuangkan Keadilan ('Adl)}

White dalam tesisnya menyimpulkan bahwa salah satu penyebab masalah lingkungan adalah agama monoteis. Doktrin agama tersebut yang kemudian menyebabkan aksi dominasi manusia terhadap alam. Perintah menguasai alam mengakibatkan munculnya pendekatan instrumental terhadap alam, tidak menghormati dan menjaga lingkungan seperti yang diajarkan Islam. Tetapi ketika White menyimpulkan bahwa agama monoteisme anti lingkungan sebenarnya lemah dan dapat di bantah, sebagaimana yang dikemukakan oleh Ustaz Apip yang mengutarakan, keberatannya jika Islam di katakan sebagai agama yang kontra lingkungan, yang menagatakan bahwa, jika disimpulkan bahwa Islam adalah agama yang menjadi pemicu kerusakan alam sebab mempunyai potensi untuk mengeksploitasinya, saya tidak setuju. Faktanya bahwa Islam sangat menjaga dan melestarikan alam seperti dalam Al-Qur'an surat Al-Jasiyah ayat 13 yang artinya "Allah menundukkan apa yang ada di langit dan apa yang ada di bumi untukmu semuanya (sebagai rahmat) dari-Nya". Bahkan Allah sangat melaknat bagi orang yang melakukan pengrusakan alam Q.S. Al-Syuraa ayat 183 yang artinya "Dan janganlah kamu merugikan manusia dengan mengurangi hak-haknya dan janganlah membuat kerusakan di bumi". Bahkan wali Songo menjadikan hutan sebagai tempat untuk kontemplasi, tirakat atau semedi (Wawancara dengan Apipudin, Pengasuh pesantren Bahrul Hidayah, Cicalengka 20 Desember 2020).

Apa yang dikemukakan oleh Ustaz Apip, mencerminkan bahwa Islam sangat peduli sekali dengan lingkungan. Bahkan Allah memperingatkan kepada manusia untuk menjaga dan merawat alam bahkan untuk memanfaatkannya harus sesuai dengan kebutuhannya. Ketika membahas lingkungan dalam kaitannya dengan teologi, pembahasan ini seringkali berkaitan 
erat dengan masalah etika, karena masalah lingkungan selalu dikaitkan dengan krisis moral dalam upaya memahami ciri-ciri saling ketergantungan antara manusia dan lingkungan.

Sesungguhnya manusia diberikan hal dalam pengelolaan alam itu diatur dan dibatasi dalam kerangka etika. Apa yang sudah berikan kepada manusia tidak serta merta manusia bebas memanfaatkannya namun ada batasan dan aturan-aturan kemanusiaan seperti; kemaslahatan, keadilan, kerahmatan. Oleh sebab itu manusia dalam memanfaatkan alam harus bersikap adil (Wawancara dengan Abdul Aziz, Pengasuh pesantren Al-Faaruuq, Cicalengka 20 Desember 2020).

Salah satu faktor dari ketidakadilan yang terjadi adalah dari program ekonomi yang di operasikan manusia. Dari waktu ke waktu program ekonomi manusia yang awal mulanya didasarkan untuk kemaslahatan manusia, menjadi dibutakan oleh hawa nafsu yang liar dengan menggunakan segala cara untuk mengembangkan ekonomi. Bumi tidak lagi dipandang dengan agama melainkan dengan materi untuk memperkaya diri, membangun cabang industri di berbagai tempat untuk memperluas jangkauan pemasaran dan mengabaikan hak dari kepentingan setiap manusia yang lain (Abdul-Matin, 2010).

Padahal, Al-Qur'an telah membatasi interaksi antara manusia dan alam dengan menjaga batasan dan melestarikannya. "Aturan pengelolaan dan pemanfaatan alam oleh manusia sebenarnya dibingkai dan dibatasi oleh perintah untuk tidak merusak, tidak rakus dan menyia-nyiakannya, tidak mengeksploitasi, tidak memboroskan diri. (berbuat mubazir), namun manusia serakah dalam mengeksploitasi alam tanpa batasan, sehingga menciptakan kerusakan alam, sebagaimana Allah mengingatkan dalam surat ar-Rum ayat 41" "Telah tampak kerusakan di darat dan di laut disebabkan karena perbuatan tangan manusia, supaya Allah merasakan kepada mereka sebahagian dari (akibat) perbuatan mereka, agar mereka kembali (ke jalan yang benar)".

\section{f. Hidup Selaras dengan Alam (Mizan)}

Islam adalah agama yang memuat berbagai ilmu dan tata kelola alam semesta yang tertulis di dalam AI-Qur'an. Dalam berbagai permasalahan lingkungan, baik itu masalah etika lingkungan maupun masalah perlindungan (perlindungan alam), masalah kerusakan lingkungan, masalah rehabilitasi alam, bahkan penyelidikan lebih jauh ke masa depan adalah masalah kerusakan alam melalui peristiwa kiamat yang akan menghancurkan alam semesta. ditemukan dalam Alquran. Sebagaimana Al-Qur'an menarasikan bahwa tujuan terciptanya alam semesta adalah untuk memenuhi kebutuhan manusia, oleh karena itu manusia diperintahkan untuk mengelola dan memanfaatkan alam sesuai dengan kebutuhannya.

Menyangkut persoalan tersebut, pesantren Al-Faaruq mempunyai cara tentang bagaimanakah memahami persoalan lingkungan kemudian bagaimana seharusnya manusia bersikap terhadap lingkungannya. Sebagaimana yang dituturkan oleh Ustaz Aziz yang mengatakan bahwa, pemahaman tentang kepedulian lingkungan di pesantren bukan tidak bisa dilakukan namun mereka kesulitan mencari cara. Jika secara teori sudah selesai, di hampir semua kitab-kitab sudah dijelaskan seperti contoh kasus, sebetulnya disadari atau tidak oleh santri ketika berbicara masalah bab salat itu secara langsung dan tidak langsung sudah membicarakan masalah kebersihan karena salah satu syarat sahnya salat itu harus bersih. Bersih itu bagaimana, bedanya kalau sudah solat dhohiron wa batinan, dohir dan batinnya harus bersih. Minimal yang dhohirnya yang kelihatan, bajunya harus bersih jangan kotor, juga tempatnya. Hal tersebut membicarakan kebersihan Cuma tidak disadari sampai ke arah sana. Jika sama ajengannya semua harus digarap maka habis waktu, maka ini harus kerja sama (Wawancara dengan Abdul Aziz, Pengasuh pesantren Al-Faaruuq, Cicalengka 11 Januari 2021).

Pesantren Bahrul Hidayah dalam kaitannya dengan konsep mizan (keseimbangan) tersebut dasarnya mengacu pada ayat Al-Qur'an yang menyebutkan bahwa sebenarnya manusia dilarang berbuat jahat setelah Allah SWT menciptakannya. Kerangka dasar teologis yang dibangun di pesantren Bahrul Hidayah merupakan upaya untuk melaksanakan tiga hubungan transenden. Hubungan pertama adalah relasi dengan Sang Pencipta, hablu mina Allah. Kedua adalah relasi dengan manusia, hablu mina an-nass. Ketiga adalah relasi dengan alam, hablu mina al-alam (Wawancara dengan Apipudin, Pengasuh pesantren Bahrul Hidayah, Cicalengka 20 Desember 2020).

Hubungan antara Tuhan-manusia-alam inilah yang menjadi kunci implementasi pemahaman ekologis yang dilakukan oleh kedua pesantren baik pesantren Al-Faaruuq maupun pesantren Bahrul Hidayah. "Ketiga hubungan tersebut merupakan terobosan dalam pandangan kiai dari pandangan konvensional selama ini yang hanya menempatkan hubungan antar manusia hanya pada dua hal, yaitu hubungan dengan Tuhan dan hubungan dengan sesama manusia Hubungan harmonis antara manusia, Tuhan dan alam dari konsep teologi lingkungan menjelaskan adanya hubungan. sistematis antara manusia, Tuhan dan alam dalam perspektif Islam teologi lingkungan".

Al-Qur'an menyampaikan kepada manusia agar selalu berpikir dalam segala tindakannya dalam berinteraksi dengan lingkungan, untuk menjaga agar lingkungan selalu tetap berada di posisi keseimbangannya. Dan memulai untuk melestarikan lingkungan dan mengambil manfaat dari lingkungan dengan sewajarnya tidak bersifat eksploitasi berlebihan yang dapat mengakibatkan hilangnya keseimbangan pada alam dan mendatangkan krisis ekologis (Abdul-Matin, 2010). Oleh sebab itu hadirnya wacana teologi lingkungan dengan mendasarkan pada bentuk teologi konstruktif yang terfokus pada hubungan antara manusia, alam dan Tuhan. Teologi lingkungan menyangkut perspektif manusia beriman bagaimana berhubungan (interaksi) antara dirinya dengan tuhan, hubungan antar manusia, maupun hubungan dengan hewan, tumbuhan, bahkan alam lingkungannya.

\section{Kesadaran Pesantren Terhadap Lingkungan}

Efek dari krisis lingkungan tentunya dapat dirasakan oleh masyarakat pesantren di Cicalengka hari ini yakni seperti perubahan iklim yang tidak menentu yang menjadi penyebabnya adalah; pertama, global warming (pemanasan global) 
hilangnya keseimbangan bumi kemudian berdampak pada ketidakjelasan antara musim kemarau dan musim penghujan. Kedua, rusaknya sumber daya alam (tanah, udara, dan air) dikarenakan banyak berdiri pabrik dan kompleks pemukiman di lahan hijau. Ketiga, deforestasi (degradasi hutan dan kebakaran hutan) yang terjadi di kawasan konservasi taman Buru Masigit Kareumbi dan kawasan penyangga lainnya seperti gunung Cibodas, dan gunung Mandalawangi yang menyebabkan musnahnya keanekaragaman hayati sehingga memicu terjadinya banjir dan longsor.

Persoalannya di pesantren adalah sampah, sampai saat ini persoalan yang paling utama adalah sampah, di pesantren dan di seputaran pesantren (masyarakat) baru sekitar 50\% terselesaikan itu juga ada tpa dari desa tapi tidak digunakan 100\% yang sisanya masih diolah ditempat. Didaerah pesantren tidak banjir sebab posisinya di atas sedangkan di bawah suka banjir. Sampai saat ini pihak pesantren masih berkoordinasi dengan pihak desa dalam menanggulangi sampah (Wawancara dengan Apipudin, Pengasuh pesantren Bahrul Hidayah, Cicalengka 20 Desember 2020).

Jika ditelusuri bahwa dampak persoalan lingkungan secara signifikan berakar dan bersumber dari perilaku manusia sendiri yang bersifat konsumtif dan eksploitatif. Ustaz Apip dalam wawancaranya, mengatakan bahwa, dampak dari rusaknya hutan dapat dirasakan oleh saya, sepeeri banjir bandang yang sering terjadi, padahal di sini merupakan dataran tinggi. Untuk mengatasi persoalan banjir, sebetulnya bukan saja tanggung jawab pemerintah saja. Namun kita sebagai manusia dan terkhusus umat beragama sangat mempunyai peran dan kesadaran dalam menjaga lingkungan sekitar. Kadang-kadang kesadaran hati bahwa buang sampah sembarangan itu dosa, kadang-kadang nyered-nyered (menyeret) air itu dosa dikarenakan mempunyai dampak terhadap masyarakat yang bisa menyebabkan banjir (Wawancara dengan Apipudin, Pengasuh pesantren Bahrul Hidayah, Cicalengka 20 Desember 2020).

Kesadaran masyarakat yang masih rendah terhadap kepeduliannya pada lingkungan, disebabkan rendahnya kesadaran masyarakat terhadap pelestarian lingkungan. Selain itu yang melatarbelakanginya yaitu faktor sosial-ekonomi yang menjadi penyebabnya. Memburuknya kondisi lingkungan di Cicalengka sebetulnya merupakan akibat tekanan dan ulah manusia yang tak lagi bersahabat dengan alam—atas ulahnya tersebut maka alam pun berontak melalui banjir dan longsor—sehingga alam tidak mau lagi ditempati oleh manusia yang tidak bersahabat. Tentunya, yang dipersalahkan bukan hanya masyarakat namun juga kebijakan pemerintah yang salah sasaran dan terkesan mengabaikan tatanan lingkungan yang hanya mementingkan pembangunan tapi tidak memedulikan dampak ekologisnya, sebagaimana disampaikan oleh pengasuh pondok pesantren AlFaaruuq, yang mengatakan bahwa, masalah tata letak lingkungan yang salah, aturan dari pemerintah tentang RTH (ruang terbuka hijau) itu masih belum bisa sepenuhnya dijalankan. Tata ruang yang digarap oleh pemerintah itu sebetulnya dasein/dassolen keharusan itu tidak sesuai dengan kenyataan. Seperti zona hijau kalau di dalam aturannya tidak boleh dibangun apalagi dibangun pabrik tapi kenyataannya banyak pabrik yang dibangun seperti di atas itu dibangunnya Dream Land. Saya adalah orang pertama yang menolak Dream Land di Cicalengka karena tujuannya bukan hanya wisata tapi disinyalir lebih kepada degradasi aqidah (Wawancara dengan Abdul Aziz, Pengasuh pesantren Al-Faaruuq, Cicalengka 11 Januari 2021).

Persoalan lingkungan yang selama ini terjadi di Cicalengka adalah masalah banjir dan longsor dikarenakan ulah manusia sendiri yang menyebabkannya. Apalagi sekarang dengan hadirnya Dream Land mempunyai dampak yang buruk bagi lingkungan. Seperti yang dikemukakan oleh anggota Basarnas yang mengatakan, kalau di Cicalengka sebetulnya banjir tidak boleh ada, namun sekarang banyak orang membuang sampah sembarangan, membangun rumah di bantaran sungai yang seharusnya melebar efeknya airnya meluap tidaknya melebar dikarenakan bangunan yang menghalanginya. Karena banyak bantaran yang dibangun rumah, warung-warung, padahal dalam aturannya di bantaran sungai itu 5 meter tidak boleh didirikan bangunan. Cicalengka rawannya di daerah atas, Tanjungwangi. Selain banjir juga rawan longsor selain faktornya karena alih fungsi lahan, juga adanya Dream Land juga sangat mempengaruhi. Di hulunya bermasalah maka dampaknya akan terasa di hilir (Wawancara dengan Iwan Ramdani, Staf SDM Kansar Bandung, Cicalengka 18 Desember 2020).

Seperti yang dipaparkan oleh ustaz Apip yang mengatakan bahwa, sekarang di Kareumbi dijadikan sebagai kawasan wisata, otomatis banyak pengunjung yang datang lebih condong pada wisatanya bukan pada konservasinya. Sedangkan kawasan hutan itu sedang sakit dan perlu perawatan. Sehingga dampaknya terasa pada masyarakat di hilirnya. Dampak luarnya dari masyarakat yang berkebun di kawasan yang menggunakan plastik sehingga air tidak terserap ke tanah dan langsung masuk sungai dikarenakan airnya langsung masuk ke sungai sedangkan lebar dan kedalaman sungainya dangkal maka airnya besar dan sungai tidak bisa menampung air. Sebelumnya para petani tidak menggunakan plastik, namun efeknya banyak tanah yang tergerus air masuk ke sungai akibatnya terjadi pendangkalan sungai. Sungai yang dangkal di tambah air yang besar dari hulu dan membawa material sampah hutan maka masuklah ke kediaman warga dengan debit air yang besar (Wawancara dengan Apipudin Pengasuh pesantren Bahrul Hidayah, Cicalengka 20 Desember 2020). Kareumbi yang tadinya berfungsi sebagai hutan konservasi, pelindung dan penyangga air Bandung timur dan Sumedang Selatan, telah beralih fungsi menjadi kawasan wisata dan areanya banyak yang dijadikan lahan pertanian oleh masyarakat sekitar yang kemudian berdampak pada terjadinya bencana alam seperti banjir bandang dan longsor (Sjoraida et al., 2019). Dampak dari rusaknya kawasan konservasi secara langsung dirasakan oleh pesantren Bahrul Hidayah karena lokasinya berdekatan.

Masalah lingkungan yang sering menimpa pondok pesantren dimana-mana adalah masalah kebersihan, karena sebagian masyarakat beranggapan bahwa lingkungan pesantren terkesan kumuh dan tidak menjaga kebersihan. Maka doktrin dan peraturan tentunya bertujuan mulia, yaitu untuk mengarahkan kepada semua santri dalam menjaga dan merawat lingkungan sekitar dengan baik dari segi kebersihan dan kebermanfaatannya. Namun kesadaran pada lingkungan di pesantren salaf masih kurang, sebagaimana dikemukakan oleh Ustaz Aziz bahwa, diakui atau tidak pesantren salaf khususnya yang tanpa 
sekolah formal kesadaran akan lingkungan itu masih kurang. Terdapat banyak faktor yang melatarbelakanginya. Salah satu faktornya karena tidak adanya tekanan dari pemerintahan melalui kedinasan terkait, karena kaitan pesantren salaf dengan pemerintah itu tidak terlalu kuat buktinya bahwa di FPP (Forum Pondok Pesantren) kabupaten Bandung yang terdaftar baru 400 an pondok pesantren padahal pondok pesantren yang ada itu lebih dari 1000 an. Dari yang 400 an itu 60\%nya salaf sisanya modern (Wawancara dengan Abdul Aziz, Pengasuh pesantren Al-Faaruuq, Cicalengka 20 Desember 2020).

Di pesantren Bahrul Hidayah santri selalu ditekankan untuk selalu menjaga kebersihan lingkungan dan diajak juga dalam memanfaatkan lahan kosong untuk ditanami pohon atau sayuran yang hasilnya kembali lagi kepada santri. Sesungguhnya dalam kesehariannya, para santri sudah di biasakan untuk selalu bersih bukan hanya saja lingkungan pesantren dan asramanya, tapi juga dirinya sendiri.

Di pondok pesantren ini hampir dua tahun kebersihan khusus di lingkungan pesantren dipaksa untuk selalu bersih dengan pola memberdayakan orang yang kurang mampu. Seperti Ato mempunyai jadwal seminggu sekali dan dibantu oleh santri untuk bersih-bersih. Siapa yang kerasan tinggal di lingkungan kotor. Sebetulnya dari konsep teologi Islam, sudah sempurna dalam Al-Qur'an disebutkan innalloha yuhibbuttawabina wa yuhibbul mutathohhirin sesungguhnya Allah menyukai orang yang bertaubat dan menyukai orang yang bersih. Penjelasan ayat itu banyak ditafsirkan dan dijelaskan oleh para ulama sampai muncul adagium "annadhofatul minal iman" sebetulnya kalimat itu untuk memotivasi umat Islam, sarana untuk menaikkan keimanan yaitu dengan kebersihan. Ujungnya dimana pun masalah kebersihan itu kembali kepada kesadaran. Kesadaran akan terbentuk apabila ada aturan, siapakah yang membuat aturan yaitu waliul amri bisyaukah (pemimpin yang sah) jelas pemimpin yang membuat aturan dan dari ketegasan aturan itu sendiri (Wawancara dengan Abdul Aziz, Pengasuh pesantren Al-Faaruuq, Cicalengka 11 Januari 2021).

Selain keteladanan, regulasi yang lebih spesifik juga diharapkan dapat ditaati bersama di pesantren. Bentuk kegiatan tersebut adalah: Pertama, adanya aturan bagi santri dan ustaz dalam menjaga kebersihan lingkungan pesantren. Bentuk dari kegiatannya sendiri adalah pesantren tersebut menetapkan suatu tatanan dimana seluruh warga yang tinggal di pesantren wajib melaksanakan dan memelihara lingkungan yang bersih dan sehat. Kedua, dibentuknya piket lingkungan. Kegiatan "piket lingkungan" merupakan kegiatan yang dilaksanakan setiap hari, dimana santri ditugaskan untuk membersihkan lingkungan pesantren setiap pagi dan sore serta secara bersama-sama membersihkan lingkungan pesantren, artinya seminggu sekali. Ketiga, penerapan sanksi bagi siswa yang tidak melaksanakan dan mendukung terciptanya lingkungan sekolah yang bersih dan sehat. Perilaku yang menunjukkan kearifan lokal juga ditunjukkan oleh santri di lingkungan pesantren, yaitu dengan menjaga lingkungan sekitar pesantren dengan menata taman, melakukan kegiatan bakti sosial bersih lingkungan, baik berupa piket, maupun bakti mingguan (Anwar et al., 2019).

Pesantren selain memberikan penyadaran pada lingkungan melalui teologi lingkungan berupa pembelajaran terhadap para santrinya, tapi pesantren juga menyediakan pengajian secara teratur bagi masyarakat sekitar. Paling tidak, penduduk sekitar pesantren mengikuti pengajian mingguan dan mendengarkan tausiyah. Dengan cara inilah maka pesantren menancapkan pengaruhnya dan memberikan pemahaman tentang teologi lingkungan kepada masyarakat.

\section{Peran Pesantren dalam Gerakan Teologi Lingkungan}

Pesantren adalah lembaga pendidikan dalam Islam yang tua dan tradisional di Cicalengka dengan beragam corak. pesantren Al-Faaruuq maupun pesantren Bahrul Hidayah keduanya mengidentifikasi sebagai pesantren salafiyah (tradisional). Mereka sangat paham mengenai segala sesuatu yang berkaitan dengan pemahaman teologi lingkungan, dan mengelola lingkungan sosial dan lingkungan alam secara luas. Pesantren dituntut mempunyai peran dalam melakukan gerakan lingkungan yang berbasis teologis, ketika organisasi keagamaan mandul dalam mengaplikasikan persoalan lingkungan. Pesantren selain menyiapkan aktivisme secara teologis, diperlukan juga pengetahuan tentang bagaimana membangun aktivisme individual dan aktivisme gerakan sosial di masyarakat, dan bagaimana mengorganisasi dan memobilisasi masyarakat dalam mempersiapkan terjadinya bencana, penanggulangan bencana, mitigasi bencana, dan aktivitas pasca bencana.

Potensi yang ada di dalam pesantren belum sepenuhnya digali, selama ini pesantren hanya diposisikan sebagai lembaga pendidikan keagamaan semata tanpa melihat sisi lain bahwa pesantren mempunyai potensi yang besar dalam pengelolaan lingkungan, hal tersebut dilirik oleh Basarnas yang melihat perlunya peran santri dan pesantren dalam mengelola lingkungan, sebagaimana yang dikemukakan oleh Iwan Ramdani, bahwa kenapa saya ingin memberikan pemahaman kepada santri, bahwasanya santri itu harus berperan.

Sebenarnya pesantren bisa dilibatkan dalam pengelolaan lingkungan sekarang ini pesantren jangan dilihat dari sisi santri yang nanti jika lulus jadi ustaz yang pola pikirnya memberikan pemahaman-pemahaman agama. Sekarang Basarnas meluncurkan program yang namanya Sar Goes To Pesantren yaitu memberikan pemahaman-pemahaman kepada santri, supaya santri juga paham bagaimana pelaksanaan teknik pencarian dan pertolongan. Tentunya selain dibekali pengetahuan tentang pencarian dan pertolongan juga mendapatkan pengetahuan tentang segala sesuatu yang berhubungan dengan lingkungan.

Selama ini pesantren-pesantren di Cicalengka sangat kurang dilibatkan dalam aktivisme lingkungan baik yang dilakukan oleh pemerintah maupun organisasi pencinta alam. Ketika melakukan gerakan lingkungan seperti penanaman pohon di lahan kritis atau gerakan bersih sungai, yang dilibatkan paling masyarakat umum dan aparatur pemerintahan setempat. Selama ini belum ada peran serta keterlibatan pihak pesantren. Namun selama ini juga Igrex's pa belum pernah mengundang ke pihak 
pesantren. Seperti di sekolah juga yang menyuruh penanaman adalah guru pembina bukan dari guru agama (Wawancara dengan Akmal, Anggota Igrex's PA, Cicalengka 18 Desember 2020).

Absennya keterlibatan pesantren dalam mengikuti kegiatan lingkungan yang di gagas baik oleh pemerintah atau organisasi pencinta alam di akui oleh ustaz Aziz yang mengatakan bahwa, harus duduk bareng antara pemerhati lingkungan, objeknya dan pemangku kebijakan bikin program atau konsep, seperti apa dan sangat disayangkan, saya ke penggerak lingkungan suka bilang bikinlah komunitas peduli lingkungan di kalangan santri yang serius digarapnya, selama ini belum kelihatan sama saya. Komunitas itu selalu di kalangan intelektual yang terlembagakan formal yang terlegitimasikan lewat ijazah disekolah atau di perguruan tinggi, termasuk pegiat lingkungan itu-itu saja terus-terusan mereka belum pernah mengajak kepada pesantren kepada santri, saya secara pribadi sebagai pengasuh pondok ahlan wasahlan wamarhaban kalau ada kelompok yang mengajak kesini meminta santri dua atau tiga untuk dijadikan sebagai kader lingkungan silahkan. Asalkan konsep dan tujuannya jelas saya persilahkan. Itu akan menjadi bibit untuk diterapkan kepada yang lain (Wawancara dengan Abdul Aziz, Pengasuh pesantren Al-Faaruuq, Cicalengka 20 Desember 2020).

Seperti yang terjadi pada pesantren Al-Faaruuq yang bergeser dari solidaritas mekanik menjadi solidaritas organis, sebagaimana dalam menyikapi keterlibatan pesantren dalam mengelola lingkungan. Sebagaimana yang dikemukakan oleh ustaz Aziz bahwa dalam mengelola lingkungan harus duduk bareng antara pesantren dengan pemerintah atau instansi terkait, dimana Pemerintah selalu mengampanyekan bahkan hampir di serentak diserukan lewat pemerintahan daerah bilang pisahkan sampah organik dan anorganik lalu dikasih 3 tong namun diberikannya ke sekolah saja sedangkan dimasyarakat, di gang-gang tidak diberikan. Pemerintah menyalahkan masyarakat hayu gotong royong bersama-sama, masyarakat juga patungan untuk mengadakan tong sampah. Seharusnya pemerintah lihat dulu kondisi lingkungan masyarakatnya, kalau kondisi masyarakatnya susah dalam menyediakan tong sampah seharusnya pemerintahnya yang menyediakan (Wawancara dengan Abdul Aziz, Pengasuh pesantren Al-Faaruuq, Cicalengka 20 Desember 2020).

Pesantren Bahrul Hidayah dasarnya adalah homogenitas mereka bergabung karena sama, sehingga ketika mereka mengadakan kegiatan apa pun ketika pesantren terlibat di sana dia tidak mengatasnamakan pesantren. Begitu juga ketika masyarakat membantu pesantren, mereka membantu karena posisinya sama sebagai masyarakat. Sedangkan Pesantren AlFaaruuq yang berada di kota bukan mereka tidak peduli secara pribadi namun berkenaan dengan pembagian kerja tugas pesantren itu berdoa atau urusan agama dalam pengertian habluminallaoh sedangkan habluminannasnya yaitu pada pendidikan (mendidik).

\section{KESIMPULAN}

Pemahaman teologi lingkungan di pesantren al-Faaruuq dan pesantren Bahrul Hidayah Melalui prinsip dasar teologi lingkungan yaitu; 1). Memahami kesatuan Tuhan dan ciptaan-Nya (tauhid) dijadikan pegangan dan pijakan dalam doktrin lingkungan, 2). Melihat tanda-tanda (ayat) Tuhan dimana saja melalui merenungi alam sebagai ciptaan Tuhan, 3). Menjadi penjaga (khalifah) di bumi, dengan cara membentuk karakter santrinya yang mempunyai tanggung jawab sebagai khalifah. 4). Menjaga kepercayaan Tuhan (amanah), merawat lingkungan sebab merupakan amanah dan nanti akan dimintai pertanggungjawaban 5). Berjuang menegakkan keadilan ('adl) membatasi pemanfaatan alam sesuai dengan kebutuhan, 6). Menjalani kehidupan yang seimbang dengan alam (mizan) yaitu melalui harmonisasi relasi manusia-Tuhan-alam. Berdasarkan ke enam poin di atas, kedua pesantren berpijak pada Al-ur'an, Sunnah Nabi, dan ulama-ulama klasik dalam memahami teologi lingkungan.

Pesantren Bahrul Hidayah mencoba memberikan penyadaran lingkungan kepada masyarakat dengan jalan mengajak untuk menjaga lingkungan, tanpa pemaksaan sedangkan kepada santrinya dengan cara memaksa. Pesantren Al-Faaruuq dalam melakukan penyadaran lingkungan kepada masyarakat yaitu harus terjalinnya kedekatan secara moral antara pesantren dengan masyarakatnya. Malahan lebih diutamakan membangun relasi dengan masyarakat ketimbang dengan lingkungan, sebab jika pesantren sudah bersinergi dengan masyarakat maka akan mudah dalam menanggulangi persoalan lingkungan. Pesantren Bahrul Hidayah dasarnya adalah homogenitas mereka bergabung karena sama, sehingga ketika mereka mengadakan kegiatan apa pun ketika pesantren terlibat di sana dia tidak mengatasnamakan pesantren. Begitu juga ketika masyarakat membantu pesantren, mereka membantu karena posisinya sama sebagai masyarakat. Sedangkan Pesantren Al-Faaruuq yang berada di kota bukan mereka tidak peduli secara pribadi namun berkenaan dengan pembagian kerja tugas pesantren itu berdoa atau urusan agama dalam pengertian habluminallaoh sedangkan habluminannas-nya yaitu pada pendidikan (mendidik).

\section{REFERENSI}

Abdul-Matin, I. (2010). Green Deen: What Islam teaches about protecting the planet. Berrett-Koehler Publishers.

Abdullah, M., \& Mubarak, M. Z. (2010). Al-Qur'an \& konservasi lingkungan: argumen konservasi lingkungan sebagai tujuan tertinggi syari'ah. Dian Rakyat.

Anwar, R. K., Sjoraida, D. F., \& Rahman, M. T. (2019). Socializing fragrant river program as a strategy for introducing environmental literacy to the upper citarum community. Journal of Environmental Management and Tourism, 10(3), 597- 
612. https://doi.org/10.14505/jemt.v10.3(35).14

Chapman, A. R., Petersen, R. L., \& Smith-Moran, B. (2008). Bumi yang Terdesak: Perspektif IImu dan Agama Mengenai Konsumsi, Populasi, dan Keberlanjutan. Mizan Pustaka.

Dhofier, Z. (1982). Tradisi pesantren: Studi tentang pandangan hidup kyai. LP3ES.

Hidup, K. L., \& Muhammadiyah, M. L. H. P. P. (2011). Teologi Lingkungan (Etika Pengelolaan Lingkungan dalam Perspektif Islam). Jakarta: Deputi Komunikasi Lingkungan Dan Pemberdayaan Masyarakat Kementerian Lingkungan Hidup Dan Majelis Lingkungan Hidup Pimpinan Pusat Muhammadiyah.

Histori.id. (2020). Kerajaan Kendan.

Islamika, I. (2016). The meaning of tumpeng in javanese Islam (a semiology analysis on tumpeng using Roland Barthes's theory). UIN Walisongo.

Kemenag. (2020). Pangkalan Data Pondok Pesantren.

Khitam, H. (2016). Kontekstualisasi Teologi sebagai Basis Gerakan Ekologi. DINIKA: Academic Journal of Islamic Studies, $1(2), 143-164$.

Magdoff, F., \& Foster, J. B. (2018). Lingkungan hidup dan kapitalisme. Marjin Kiri.

Mangunjaya, F. M. (2014). Ekopesantren: Bagaimana merancang pesantren ramah lingkungan? Yayasan Pustaka Obor Indonesia.

Moleong, L. J. (2007). Metodologi Penelitian Kualitatif. Remaja Rosdakarya.

Muhammad, A. S., Mumammad, H., Mabrur, K. H. R., Abbas, A. S., Firman, A., Mangunjaya, F. M., Pasha, K. I. B., \& Andriana, M. (2006). Fiqih Lingkungan. Jakarta: Conservation International Indonesia.

Mujiyono, A. (2001). Agama Ramah Lingkungan Perspektif Al-Quran. Jakarta: Paramadina.

Murtadho, A. (2019). Gerakan lingkungan Kaum Muda NU: studi tentang pemikiran dan aksi Gerakan Sosial Front Nahdliyin untuk Kedaulatan Sumber Daya Alam/FNKSDA. UIN Sunan Ampel Surabaya.

Nașr, Husain, \& Nasr, S. H. (1996). Religion \& the order of nature (Issue 167). Oxford University Press on Demand.

Niman, E. M. (2019). Kearifan lokal dan upaya pelestarian lingkungan alam. Jurnal Pendidikan Dan Kebudayaan MISSIO, 11(1), 91-106.

Sanapiah, F. (1995). Format-format Penelitian Sosial, Dasar-dasar dan Aplikasi. Jakarta: Rajawali Pers.

Sjoraida, D. F., Anwar, R. K., \& Rahman, M. T. (2019). Post-flood handling pattern by self-sufficient community in Garut. IOP Conference Series: Earth and Environmental Science, 311(1), 12050.

Sururi, A. (2014). Menggapai Pelestarian Lingkungan Hidup di Indonesia: Studi Perbandingan Etika Islam dan Etika Ekofeminisme. Fikrah, 2(1).

Suyatman, U. (2018). Teologi Lingkungan dalam Kearifan Lokal Masyarakat Sunda. Al-Tsaqafa: Jurnal IImiah Peradaban Islam, 15(1), 77-88. conditions of the Creative Commons Attribution (CC BY SA) license (http://creativecommons.org/licenses/by-sa/4.0/). 